\title{
Flexural Behaviour of Partially Prestressed Reinforced Baked Clay Beams
}

\author{
Muhammad Auchar ZARDARI, Nawab Ali LAKHO
}

\begin{abstract}
To provide shelter for slum dwellers of Pakistan, Reinforced Baked Clay (RBC) seems to be a possible option to replace Reinforced Cement Concrete (RCC) whose ingredients, i.e., aggregates and cement are costly in plains of the country. However, shear failure is a major problem observed in RBC beams. In addition, it is difficult to provide shear reinforcement in RBC beams, because it is time consuming and it does not contribute to resist shear stresses. In this study, a technique is presented to overcome problem of shear failure of RBC beams. The RBC beams were partially prestressed by post tensioning up to $60 \%$ of yield stress and were tested in three points loading. The results show that the RBC beams (i) exhibited flexural mode of failure without shear reinforcement, (ii) carried as much load as control RCC beam. This implies that by partial prestressing of RBC beams, there could be no need of shear reinforcement. This will result in saving of time and money.
\end{abstract}

Keywords: baked clay; crack width; deflection; low-cost houses; partial prestressing; shear failure

\section{INTRODUCTION}

It is not affordable for low income people, in Pakistan, to construct houses made of Reinforced Cement Concrete (RCC). This is due to high cost of construction materials such as cement, aggregates, and steel. In Pakistan, low income people live in slums without having basic facilities necessary for living. To resolve this problem, one of the options is to utilize clay as a material of construction in plain areas of the country. The idea is to erect buildings using precast structural panels of Reinforced Baked Clay (RBC) beams, columns, and slabs.

Population of Pakistan in 2017 was about 207 million people. The population grew at a rate of $2.4 \%$ annually from 1998-2017 [1]. It is estimated that currently there is a shortfall of over 9 million housing units in Pakistan [2].

It is relevant to mention here that baked clay bricks have been used in construction of buildings since thousands of years ago [3]. Such buildings are durable to resist extreme weather conditions. With the availability of technology and technical knowledge regarding RCC, it is now possible to extend the size of baked clay specimen from traditional brick to beams, columns, and slabs. However, extensive research is needed to understand structural behaviour of RBC under various loading conditions.

In this regard, preliminary research has been carried out on structural properties of RBC beams. Initially it was tried to obtain compressive strength of baked clay as high as that of normal concrete. The target compressive strength of normal concrete was taken as $20 \mathrm{MPa}$ [4]. The studies suggest that in addition to firing temperature [5-9], compression applied during casting of beams [10] plays an important role in increasing compressive strength of baked clay. The structural properties of RBC beams were investigated in terms of compressive strength [11], modulus of rupture [12], and load versus deflection response under static loading [13-19] and impact loading $[20,21]$. The problems of shrinkage and cracking of clay beams during dying [22] and firing process [23] are also addressed.

The houses made of RBC are low-cost as compared to the ones constructed of RCC. The supporting arguments in favour of $\mathrm{RBC}$ as a low-cost material of building construction are: clay is locally available in vast quantity, cement and aggregates are not required; proper baking of clay gives good look and colour so there will be no need of plastering and painting [16].

In a previous study [16], reinforced baked clay beams of $150 \mathrm{~mm}$ width, $300 \mathrm{~mm}$ depth and $1950 \mathrm{~mm}$ length were tested in flexure with: (i) three-point loading, and (ii) uniformly distributed load. In both loading conditions, the beams showed shear mode of failure. To control shear mode of failure of these RBC beams, vertical bars were used as shear reinforcement. Consequently, flexural cracks developed at the location of vertical bars in addition to diagonal cracks near the supports. It is pertinent to mention here that provision of shear reinforcement in baked clay beams is not easy like RCC beams. Initially a clay beam is baked and then shear reinforcement could be placed by drilling vertical holes at some spacing throughout the length of the specimen. Therefore, it is very important to resolve the issue of shear failure of the $\mathrm{RBC}$ beams.

From structural point of view, like ceramics, baked clay is both brittle and fragile material. Due to these drawbacks, baked clay beams may crack during handling and transportation. To address the above-mentioned issues, an attempt was made to utilize partial prestressing of baked clay beams to reduce their fragility, improve durability and shear resistance. To the best of knowledge of authors, no such study is reported on baked clay beams.

Partial prestressing of a structural member is defined as a technique in which tensile stresses and limited cracks can develop under working loads [24, 25]. It might be possible to obtain a safe and economical structure by using a suitable degree of prestressing [24].

For this purpose, an experimental study was conducted to investigate the structural behaviour of partially prestressed RBC beams under concentrated load.

\section{MATERIALS AND METHODS \\ 2.1 Casting of Beams}

Clay and pit sand were quarried in the surrounding of Nawabshah, Sindh, Pakistan. Clay was excavated below depth of $1000 \mathrm{~mm}$. At this depth, the clay was free from organic matter and vegetation. In-situ moisture content of the samples of excecated clay and pit sand were found to be $12 \%$, and $8 \%$, respectively. The pit sand being 
coarse material was non- plastic and the plasticity index of clay was $12 \%$.

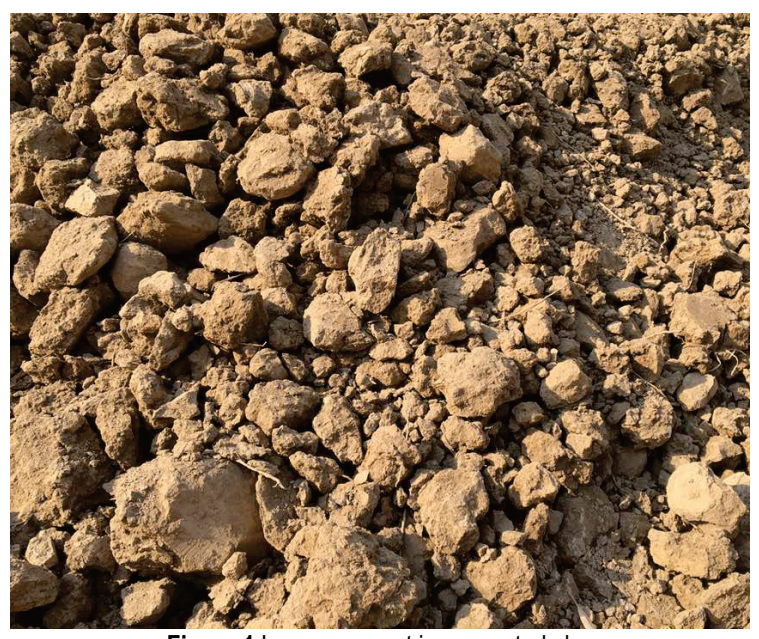

Figure 1 Lumps present in excavated clay
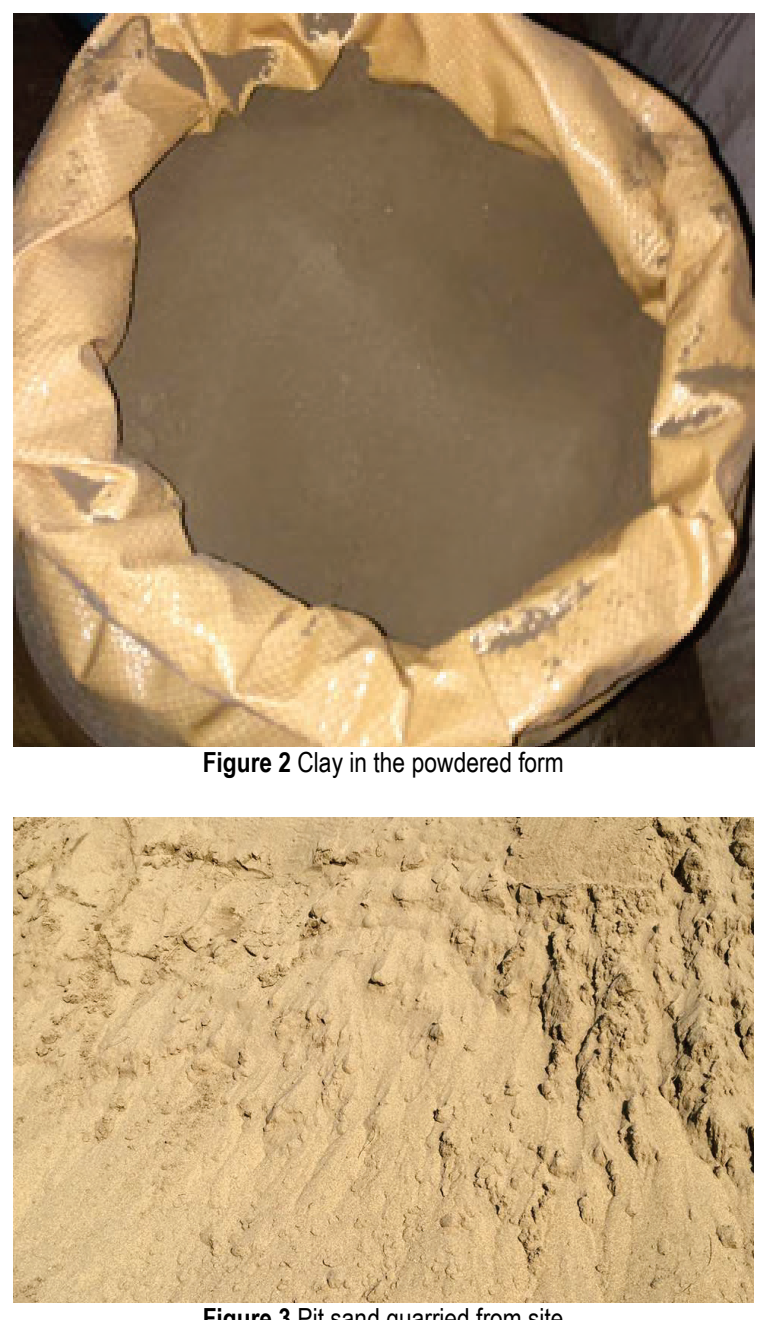

Figure 3 Pit sand quarried from site

The clay quarried from the site was in the form of lumps (Fig. 1), therefore, it was pulverized into the powdered form (Fig. 2). To minimize drying shrinkage of earth beams, $70 \%$ clay and $30 \%$ pit sand (Fig. 3), by weight, were mixed with $20 \%$ water [16]. Mixing of clay and pit sand mixture was performed in a pan mixer for fifteen minutes. For convenience, the mixture of clay and pit sand will hereafter be referred to as clay in this paper.
The focus of this type of research is to obtain compressive strength of baked clay as high as normal concrete. The cube crushing strength of baked clay is associated with its density which is maximum at optimum water content. The optimum moisture content of clay and pit sand mixture used in this study was found to be $12 \%$. This amount of water is not sufficient for developing proper plasticity which is an important property of clay to allow moulding into any shape without breaking. Therefore, water content of the clay was increased to $20 \%$ for proper moulding and workability. This increase in moisture content may decrease the density of clay beams after drying that may result in low compressive strength both in unbaked and baked conditions. In addition to this, if water content in clay is higher, more shrinkage may occur resulting in drying cracks. These drying cracks may deteriorate structural performance of the clay beams. To address these technical problems, it was necessary to cast the clay beams at water content of $20 \%$ and then get the extra added water expelled by mechanical means to the extent of optimum water content.

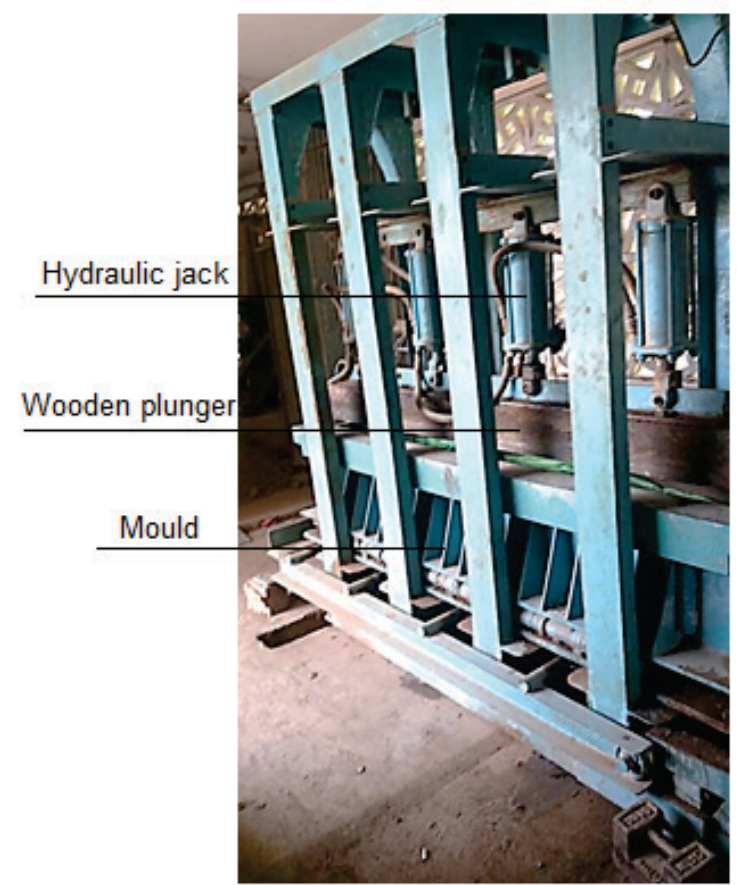

Figure 4 Wooden plunger of the mechanized system is used to press the clay beams

Moist clay and pit sand mixture was placed in steel mould (Fig. 4) in five layers of equal depth. Slight tamping was applied on each layer before placing the next one. The clay pit sand mixture was covered with porous propylene sheet. The size of the mould was $165 \times 400 \times 1980 \mathrm{~mm}$. The size of the beams cast in this mould was maintained to be $330 \mathrm{~mm}$ in depth. The clay beams were compressed at a pressure of $6 \mathrm{MPa}$ with the help of wooden plunger of the Mechanized System [26] as shown in Fig. 4. This compressive pressure was maintained for 24 hours. When the compressive pressure was applied, water started to expel from moist clay and pit sand mixture. After 24 hours of the application of compressive pressure, water content of clay beams was reduced to $13 \%$ which is close to the optimum water content. After compaction, the clay beams were demoulded (Fig. 5). 


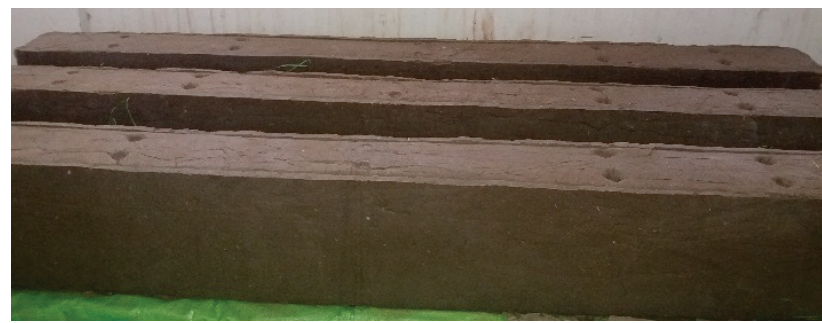

Figure 5 Clay beams after demoulding from the mould

To place tensile reinforcing bars in the beams, two perforations, each of $25 \mathrm{~mm}$ diameter, were made by inserting $25 \mathrm{~mm}$ polished steel bars during casting. These bars were then pulled out after the beams were cast and compacted. At this experimental stage, no protective pipes were used in the perforations for reinforcement. The beams were covered with plastic sheet and were dried in shade to curtail possibility of drying cracks. After drying, the beams were fired in a kiln at $900{ }^{\circ} \mathrm{C}$.

\subsection{Cutting of Baked Clay Cubes and Beams}

To determine compressive strength of these baked clay beams, cubes of $150 \mathrm{~mm}$ were cut using cutter machine. These clay beams shrunk after drying in shade and firing in kiln. The baked clay beams were trimmed with cutter and size of $150 \times 300 \times 1930 \mathrm{~mm}$ was maintained. The baked clay beams were sawed and trimmed as per guidelines mentioned in ASTM C42/C42M [27].

\subsection{Prestressing Rig}

A prestressing rig (Fig. 6) was designed and fabricated to apply partial prestressing to reinforced baked clay beams. The rig contains the following parts.

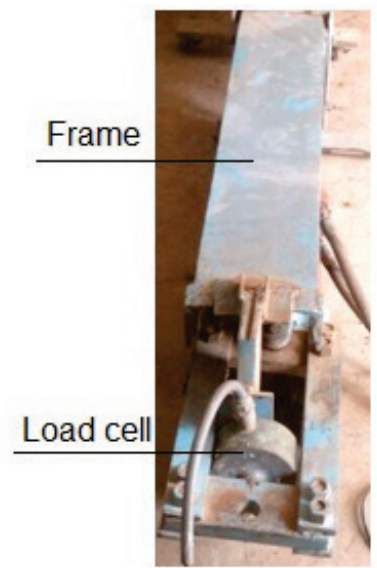

Figure 6 Baked clay beam being post tensioned with the help of prestressing rig

Frame: The frame consists of two channel sections welded to each other. At one end of the frame, steel plates are bolted to place a load cell between them (Fig. 6). The frame is so designed that at its one end, the jack cylinder is pinned and on the other end the reinforcing bars can be pulled through a U-shaped steel hook (Fig. 7).

Hydraulic Jack: The reinforcing bars were pulled with hydraulic jack (Fig. 8). The load carrying capacity of this hydraulic jack is 40 tonnes. The diameter of piston rod of the jack was $100 \mathrm{~mm}$.

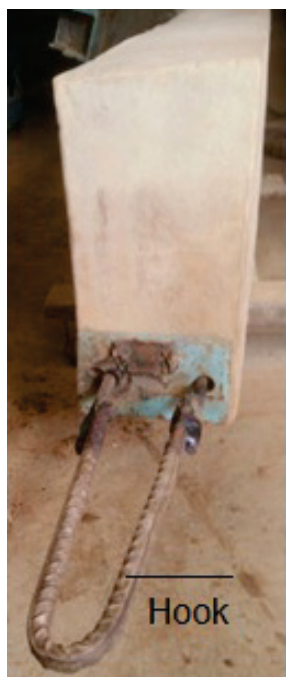

Figure $7 \mathrm{~A}$ hook is welded with reinforcing bars of the beam

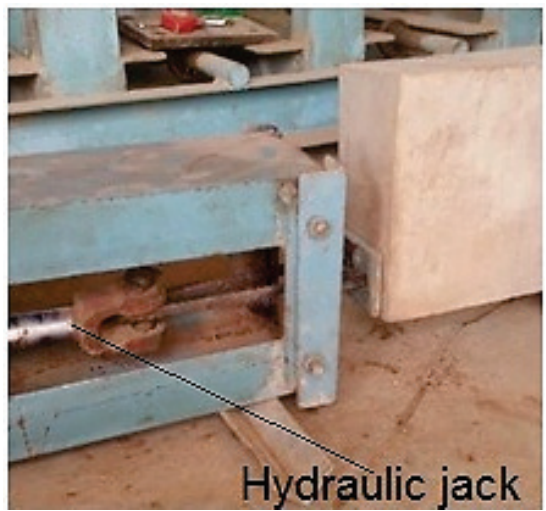

Figure 8 Steel reinforcing bars are being partially prestressed using hydraulic jack

Load Cell and Display: The prestressing rig is so designed that a $100 \mathrm{kN}$ load cell can be fitted easily while prestressing the beams. During this process, the display shows continuously the loading history of the prestressing of the bars. With the help of this prestressing rig, the reinforcing bars were prestressed up to $60 \%$ of yield stress.

\subsection{Prestressing of Baked Clay Beams}

Deformed mild steel bars of grade 60 that were used in this study were of the following properties: diameter of bars $12.7 \mathrm{~mm}$, yield strength $420 \mathrm{MPa}$, ultimate tensile strength $620 \mathrm{MPa}$, and minimum elongation 9\% [28].

The compressive strength of baked clay being discussed in this paper was $30 \mathrm{MPa}$. The details of compressive strength of baked clay are presented in coming sections of this paper. The reinforced baked clay beams of size $150 \times 300 \mathrm{~mm}$ were designed as under reinforced beams as per guidelines of ACI code [29]. Two steel bars, each having diameter of $12.7 \mathrm{~mm}$, were inserted in pre-perforated holes in the beam as tensile reinforcement (Fig. 9). Neither compressive nor shear reinforcement was provided in the beams. Two $150 \mathrm{~mm}$ steel plates having thickness of $12.7 \mathrm{~mm}$ were used as anchor plates at both ends of the beams. One of these steel plates was welded with the ends of the reinforcing steel bars. The second plate was placed at the other end of the beam. A U-shaped hook was welded to the ends of the bars. The bars were prestressed with the help of prestressing rig using the hook. 
When the prestressing reached up to $60 \%$ of yield strength of mild steel, the bars were welded to the steel plate and hook was detached from the bars after releasing the prestressing force.

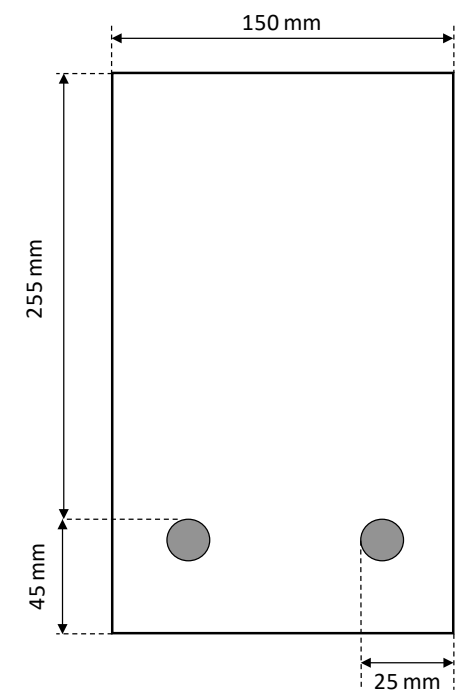

Figure 9 Section of reinforced baked clay beam

As mentioned earlier the baked clay beams were reinforced in tension zone only. No reinforcement was provided in compression zone. When a reinforced baked clay beam is prestressed in tension zone, the length of beam may shorten in tension zone, and elongate in compression zone. As a result, tensile stresses may develop in compression zone. If the tensile stresses in the compression zone exceed the flexural tensile strength of the baked clay, the beam may fail abruptly during partial prestressing process. Therefore, the partial prestressing of the tensile reinforcement was gradually increased to $60 \%$ of the yield strength of the mild steel. It was observed that the developed tensile stresses in the compression zone were below the flexural tensile strength of baked clay.

\section{TEST PROCEDURES}

Ten cubes of baked clay having size of $150 \mathrm{~mm}$, were sawed from the baked clay beams and tested for compressive strength in Forney's Universal Testing Machine [30] as illustrated in Fig. 10. British standard BS EN 12390-3 [31] procedure was followed for testing of cube crushing strength of baked clay.

Five plain baked clay beams (P1, P2, P3, P4 and P5) were tested for flexural tensile strength in terms of modulus of rupture using Torsee's Universal Testing Machine [32]. The section of the plain baked clay beams was $150 \times 300$ $\mathrm{mm}$ and the total and effective lengths were $850 \mathrm{~mm}$ and $900 \mathrm{~mm}$, respectively. The beams were placed on roller supports at the ends and the load was applied at midspan.

The modulus of rupture of the plain baked clay beams was determined as per guidelines provided in ASTM C293/C293M [33]. The beams were placed on roller supports and load was applied at midspan (Fig. 11).

Modulus of rupture was calculated using the following formula [33]:

$$
R=\frac{P \cdot L}{b \cdot d^{2}}
$$

where $R$ represents modulus of rupture $(\mathrm{MPa}), P$ indicates load $(\mathrm{N}), L$ shows span length $(\mathrm{mm}), b$ is the width and $d$ is the depth of beam ( $\mathrm{mm})$.

The modulus of rupture of normal concrete $\left(f_{\mathrm{r}}\right)$ was calculated using the following relationship suggested by ACI 318-11 [29]:

$$
f_{\mathrm{r}}=0.7 \sqrt{f_{\mathrm{c}}}
$$

where $f_{\mathrm{c}}$ represents cylindrical compressive strength of concrete in $\mathrm{MPa}$.

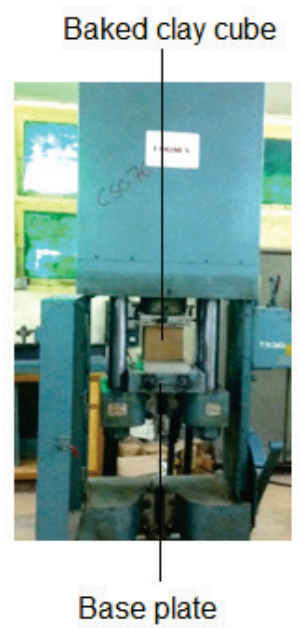

Figure 10 Baked clay cubes are being compressed in the Universal Testing Machine to determine compressive strength



Figure 11 Determination of flexural tensile strength of baked clay in Torsee's universal testing machine

Three partially prestressed RBC beams (B1, B2 and B3) of dimensions $150 \times 300 \mathrm{~mm}$ and effective length of $900 \mathrm{~mm}$ were also tested using Torsee's Universal Testing Machine [30] to investigate load versus deflection response and crack behaviour. The total length of the partially prestressed RBC beams was $1000 \mathrm{~mm}$. During testing, the partially prestressed RBC beams were supported on roller supports at both ends and the load was applied at midspan. The load at midspan was applied gradually. 
To avoid stress concentration at the point of loading, a square steel plate of $150 \mathrm{~mm}$ sides and $12.7 \mathrm{~mm}$ thick was placed at midspan of both the plain baked clay beams and partially prestressed reinforced baked clay beams.

\section{RESULTS AND DISCUSSION}

The results discussed in this study are: compressive strength of baked clay cubes, flexural tensile strength of plain baked clay beams, load versus deflection response and crack behaviour of partially prestressed RBC beams.

\subsection{Compressive Strength of Baked Clay}

The average compressive strength of the ten baked clay cubes was $30 \mathrm{MPa}$, whereas the compressive strength of normal concrete is $20 \mathrm{MPa}$ [5]. This implies that cube crushing strength of baked clay discussed in this study is 1.5 times more than that of normal concrete. The standard deviation and coefficient of variation of cube crushing strength were 0.45 , and $1.48 \%$, respectively.

\subsection{Flexural Tensile Strength of Baked Clay}

The magnitude of modulus of rupture of five plain baked clay beams (P1, P2, P3, P4 and P5) is presented in Tab. 1. Average modulus of rupture of baked clay was found to be about $5 \mathrm{MPa}$. The standard deviation of the modulus of rupture was $0.19 \mathrm{MPa}$.

Table 1 Evaluation of modulus of rupture of plain baked clay beams

\begin{tabular}{|c|c|c|}
\hline Description & $\begin{array}{c}\text { Failure load } \\
(\mathrm{kN})\end{array}$ & $\begin{array}{c}\text { Modulus of rupture } \\
(\mathrm{MPa})\end{array}$ \\
\hline P1 & 52 & 4.8 \\
\hline P2 & 53 & 5 \\
\hline P3 & 55 & 5.2 \\
\hline P4 & 56 & 5.3 \\
\hline P5 & 54 & 5.1 \\
\hline Average & 54 & 5.08 \\
\hline Standard deviation & & 0.19 \\
\hline
\end{tabular}

To present comparison of modulus of rupture of fired clay with that of concrete, the modulus of rupture of the latter was evaluated with the help of empirical Eq. (2). For normal concrete having compressive strength of $20 \mathrm{MPa}$, the magnitude of modulus of rupture is about $3 \mathrm{MPa}$. The modulus of rupture of fired clay is about 1.6 times higher than that of normal concrete. It is to be noted that the tensile resistance of a material is evaluated by its modulus of rupture. The ratio of modulus of rupture of fired clay to its compressive strength is about 0.16 . On the other hand, for normal concrete, the ratio of modulus of rupture to compressive strength is 0.10 . This implies that fired clay could show better performance in resisting tensile stresses in comparison to normal concrete. This indicates that less amount of tensile reinforcement could be needed in RBC compared to RCC. This suggests that fired clay could serve as low cost building construction material as compared to normal concrete.

\subsection{Load Versus Deflection Response}

Load versus deflection response of three partially prestressed RBC beams (B1, B2 and B3) and one control
RCC beam composed of normal concrete is presented in Fig. 12. The dimensions and reinforcement of both types of beams is the same. However, the reinforcement in the concrete beam was simply embedded during casting and partial prestressing was not applied. The average yield strength of RBC beams (about $57 \mathrm{kPa}$ ) was similar to that of RCC beam (cf. Fig. 12 and Tab. 2). On average, the RBC beams carried a load of $70 \mathrm{kN}$ (Tab. 2). The ultimate strength of both the RBC beams and the control RCC beam was almost similar. Standard deviation of both the yield strength and ultimate strength of the RBC beams was about $0.58 \mathrm{MPa}$.

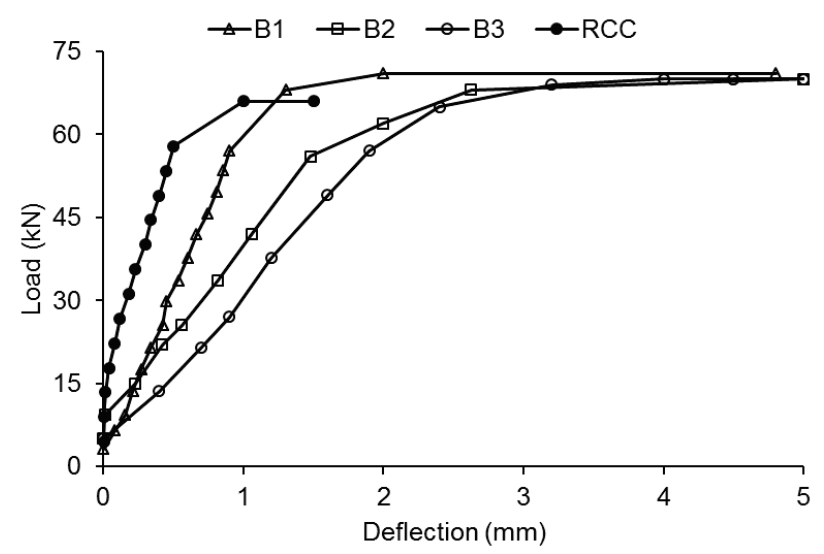

Figure 12 Load versus deflection response of partially prestressed baked clay beams compared with RCC beam made of normal concrete with compressive strength of about $20 \mathrm{MPa}$

Table 2 Yield and ultimate strength of reinforced baked clay beams

\begin{tabular}{|c|c|c|}
\hline Beam ID & $\begin{array}{c}\text { Yield strength } \\
(\mathrm{MPa})\end{array}$ & $\begin{array}{c}\text { Ultimate strength } \\
(\mathrm{MPa})\end{array}$ \\
\hline B1 & 57 & 71 \\
\hline B2 & 56 & 70 \\
\hline B3 & 57 & 70 \\
\hline Average & 56.7 & 70.3 \\
\hline Standard deviation & 0.58 & 0.58 \\
\hline
\end{tabular}

The RBC beams showed three times more deflection as compared to control RCC beam. The possible reason for more deflection in RBC beams is due to the slip of bond between baked clay and reinforcing bars. The bars were stretched throughout their full length. Thus resulted in more increase in length due to application of load. Whereas, in case of RCC, due to significant bond between reinforcing bars and concrete, there was no slip between the bars and concrete. The elongation of bar occurred only in small fraction of length which was equal to the summation of total widths of cracks in tensile zone of the beam. Since this sum of widths of cracks is very small as compared to the full length of the beam, therefore, less deflection was observed in RCC beam as compared to that of RBC beams. It could be interpreted that with increase in diameter of bars, bond slippage and deflection in RBC beams may be reduced.

From Fig. 12 it can be observed that the partially prestressed baked clay beam B1 showed less initial deflection as compared to the beams B2 and B3. This is because of slight variation in position of the tensile reinforcement with respect to top compression fiber of the RBC beams. As mentioned earlier, $25 \mathrm{~mm}$ diameter perforations were made in the clay beams during casting. 
During drying process, internal diameter of these perforations and their shape might have been changed due to shrinkage and internal warping. Since the steel bars having diameter of $12.7 \mathrm{~mm}$ were inserted through these perforations and were prestressed. This implies that due to drying shrinkage and internal warping of clay beams, there may be the possibility of slight variation of effective depth of the RBC beams.

\subsection{Development of Cracks and failure mode of Partially Prestressed RBC Beams}

In each of the partially prestressed RBC beams tested, only one crack occurred at tension zone near mid span (Figs. 13 and 14). With further increase in load, only the width of the first crack increased (Figs. 15 and 16) and no any other crack was opened until the ultimate failure. At ultimate failure of the RBC beams, neither longitudinal cracks nor spalling of the material occurred (Figs. 17 and 18). In addition to this, there were no diagonal cracks. The mode of failure of the partially prestressed RBC beams was flexural by occurrence of single crack at tension zone near midspan. No sign of shear crack was observed. This is an important finding that by utilizing partial prestressing technique mentioned in this study, the shear cracks did not develop in RBC beams without providing shear reinforcement. This implies that both time and money could be saved by utilizing partially prestressed RBC beams instead of RCC ones for construction of low cost houses.

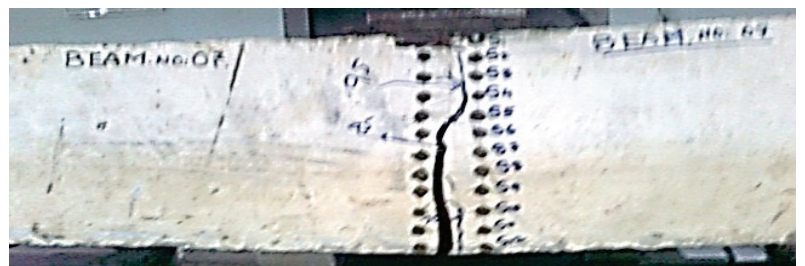

Figure13 Opening of initial single crack at midspan of partially prestressed reinforced baked clay beam $B$

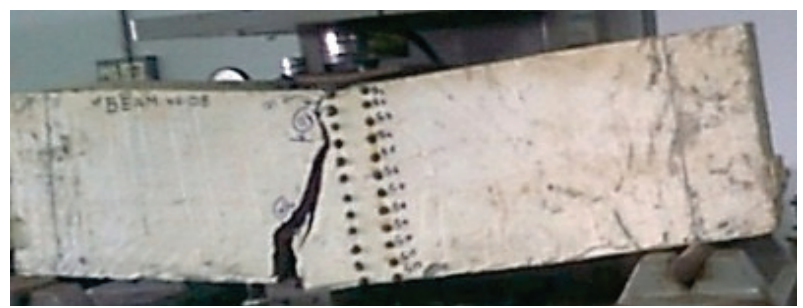

Figure 14 Opening of initial single crack near midspan of partially prestressed reinforced baked clay beam $B 2$



Figure 15 Widening of initial crack at midspan of partially prestressed reinforced baked clay beam $\mathrm{B} 1$

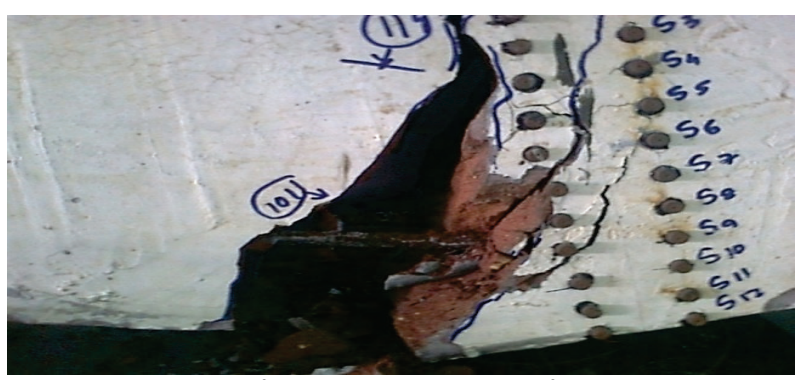

Figure 16 Widening of initial crack near midspan of partially prestressed reinforced baked clay beam $\mathrm{B} 2$



Figure 17 Ultimate failure of partially prestressed reinforced baked clay beam $\mathrm{B} 1$

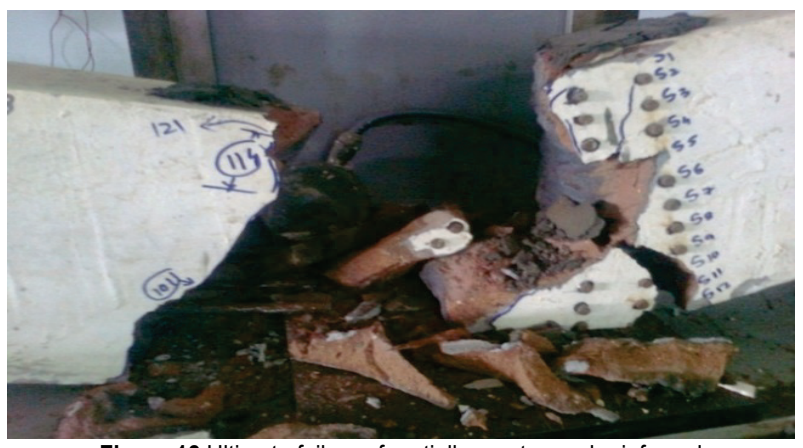

Figure 18 Ultimate failure of partially prestressed reinforced baked clay beam B2

\section{CONCLUDING REMARKS}

In order to control shear failure of Reinforced Baked Clay beams, a technique of partial prestressing is presented in this paper.

The following conclusions were drawn from the testing of partially prestressed Reinforced Baked Clay (RBC) beams under three points loading:

1) Baked clay, when partially prestressed in tension only, becomes strong enough to sustain shear, diagonal and longitudinal cracks without providing any stirrups.

2) The load carrying capacity of partially prestressed RBC beams was almost same as that of control Reinforced Cement Concrete (RCC) beam.

3) Partially prestressed RBC beams showed flexural mode of failure. This resulted in splitting of beams into two halves after cracking of beams and yielding of reinforcing steel bars.

4) Partially prestressed $\mathrm{RBC}$ beams showed three times more deflection than control RCC beam due to insufficient bond developed between baked clay and the reinforcement.

Future study is required to control deflection in partially prestressed RBC beams up to the level of normal 
concrete beams. In addition, numerical analysis based on finite element method could be interesting to compare experimental and theoretical results of load versus deflection and crack behaviour of RBC beams.

\section{REFERENCES}

[1] Provisional summary results of 6th population and housing census-2017 (2018, February 17). Retrieved from http://www.pbs.gov.pk/content/provisional-summaryresults-6th-population-and-housing-census-2017-0.

[2] Iqbal, S. (2015, January 25). Housing shortage reaches 9m units: State Bank. Dawn, Retrieved from https://www.dawn.com/news/1159259/housing-shortagereaches-9m-units-state-bank.

[3] Pearson, D. (1998). The new natural house book: creating a healthy, harmonious, and ecologically sound home. Simon and Schuster.

[4] Neville, A. M. (1995). Properties of concrete (Vol. 4). London: Longman.

[5] Johari, I., Said, S., Hisham, B., Bakar, A., \& Ahmad, Z. A. (2010). Effect of the change of firing temperature on microstructure and physical properties of clay bricks from Beruas (Malaysia). Science of Sintering, 42(2), 245-254. https://doi.org/10.2298/SOS1002245J

[6] Agbede, O. A., Oluokun, G. O., Olayemi, O. K., Jayeioba, K. F., \& Oke, A. M. (2016). Impact of Firing Temperature on Compressive Strength Characteristics of Lateritic Bricks. International Journal of Latest Research in Engineering and Technology, 2(10), 50-55.

[7] Karaman, S., Ersahin, S., \& Gunal, H. (2006). Firing temperature and firing time influence on mechanical and physical properties of clay bricks. Journal of scientific and industrial research, 65, 153-159.

[8] Karaman, S., Gunal, H., \& Ersahin, S. (2006). Assessment of clay bricks compressive strength using quantitative values of colour components. Construction and Building Materials, 20(5), 348-354. https://doi.org/10.1016/j.conbuildmat.2004.11.003

[9] Mbumbia, L., de Wilmars, A. M., \& Tirlocq, J. (2000). Performance characteristics of lateritic soil bricks fired at low temperatures: a case study of Cameroon. Construction and Building Materials, 14(3), 121-131. https://doi.org/10.1016/S0950-0618(00)00024-6

[10] Lakho, N. A., Zardari, M. A., \& Memon, F. A. (2016). Effect of intensity of compaction on crushing strength of indigenous baked clay. Journal of Engineering Research, 4(2), 17-28. https://doi.org/10.7603/s40632-016-0011-5

[11] Lakho, N. A. \& Zardari, M. A. (2016). Relation between Compressive Strength of Baked Clay Cubes and Cylinders. Engineering, 8, 509-514. https://doi.org/10.4236/eng.2016.88047

[12] Lakho, N. A., \& Zardari, M. A. (2016). Comparison of Compressive and Tensile Strength of Baked Clay with those of Normal Concrete. Engineering, 8, 301-307. https://doi.org/10.4236/eng.2016.86027

[13] Lakho, N. A. \& Zardari, M. A. (2016). Flexural Behaviour of Reinforced Baked Clay Beams. Engineering, 8, 403-409. https://doi.org/10.4236/eng.2016.87037

[14] Lakho, N. A. \& Zardari, M. A. (2017). Long-term flexural behaviour of reinforced baked clay beams. Scientia Iranica, 24(3), 877-883. https://doi.org/10.24200/sci.2017.4072

[15] Lakho, N. A. \& Zardari, M. A. (2016). Effect of Reinforcement on Deflection and Cracks in Baked Clay Beams. Engineering, 8, 684-690. https://doi.org/10.4236/eng.2016.810062

[16] Ansari, A. A. (2008). Experimental Study of the Behaviour of Pre-Perforated Post-reinforced baked Clay Panels of
Beams. PhD Thesis, Quaid-e-Awam University of Engineering Science and Technology, Nawabshah.

[17] Ansari, A. A., Bhatti, N. K., \& Bhutto, A. (2013). Suitability of pre-perforated post-reinforced baked clay beam panels for low cost housing. American Journal of Civil Engineering, l(1), 6-15. https://doi.org/10.11648/j.ajce.20130101.12

[18] Ansari, A. A., \& Lakho, N. A. (2013). Determination of Structural Properties of Baked Clay as Replacement of RCC. International Journal of Emerging Technology and Advanced Engineering, 3(2), 17-25.

[19] Memon, A. B., Bhatti, N. K., \& Ansari, A. A. (2013). Emergence of new era for reinforced baked clay construction. Quaid-e-Awam University Research Journal of Engineering, Science and Technology,12(2),1-8.

[20] Lakho, N. A. \& Zardari, M. A. (2016). Experimental Study of Flexural Behaviour of Reinforced Baked Clay Beams under Impact Loading. Engineering, 8, 347-352. https://doi.org/10.4236/eng.2016.86032

[21] Lakho, N. A. \& Zardari, M. A. (2016). Effect of Reinforcement on Deflection and Cracks in Baked Clay Beams Subjected to Impact Loading. Engineering, 8, 691696. https://doi.org/10.4236/eng.2016.810063

[22] Lakho, N. A., Zardari, M. A., \& Memon, N. A. (2015). Reduction of Cracking and Shrinkage in Compressed Clay Beams during Drying. Mehran University Research Journal of Engineering and Technology, 35(3), 395-400. https://doi.org/10.22581/muet1982.1603.09

[23] Lakho, N. A., Zardari, M. A., \& Memon, N. A. (2016). Effect of Firing on Cracking and Warping of Clay Beams. Mehran University Research Journal of Engineering and Technology, 35(2), 247-252.

[24] Hassoun, M. N. \& Manaseer, A. A. (2012). Structural concrete: Theory and design. Hoboken, New Jersey: John Wiley \& Sons, Inc.

[25] Nilson, A., Darwin, D., \& Dolan, C. W. (2010). Design of concrete structures, New York: McGraw Hill.

[26] Lakho, N. A., Zardari, M. A., Memon, M., \& Saand, A. (2015). Design and fabrication of mechanized system for casting and compacting laboratory size clay beams. Scientia Iranica, 22(6), 2046-2051.

[27] ASTM C42/C42M (2013). Standard Test Method for obtaining and Testing Drilled Cores and Sawed Beams of Concrete. ASTM International, West Conshohocken.

[28] Mechanical Properties of Deformed Bar G-60 (2018, February 20). Retrieved from http://amrelisteels.com/ deformed-bars-g-60/

[29] Building Code Requirements for Structural Concrete (ACI 318-11) and Commentary. (2011). American Concrete Institute 38800 Country Club Drive Farmington Hills, MI 48331 U.S.A.

[30] Forney's Universal Testing Machine. Forney LP 2050 Jackson's Pointe Court Zelienople, PA 16063, US.

[31] BS EN 12390-3. Testing hardened concrete - Part 3: Compressive strength of test specimens (2002).

[32] Torsee's Universal Testing Machine. Tokyo testing machine, MFG., CO., LTD.

[33] ASTM C293/C293M (2016). Standard Test Method for Flexural Strength of Concrete (Using Simple Beam with Center-Point Loading), ASTM International, West Conshohocken, PA. 


\section{Contact information:}

Muhammad Auchar ZARDARI, PhD, Assistant Professor

(Corresponding author)

Department of Civil Engineering,

Quaid-e-Awam University of Engineering, Science and Technology,

Nawabshah, 67480, Sindh, Pakistan

E-mail: muhammad.auchar@quest.edu.pk

Nawab Ali LAKHO, PhD, Assistant Professor

Department of Civil Engineering,

Quaid-e-Awam University of Engineering, Science and Technology,

Nawabshah, 67480, Sindh, Pakistan

E-mail: nawablakho@gmail.com 